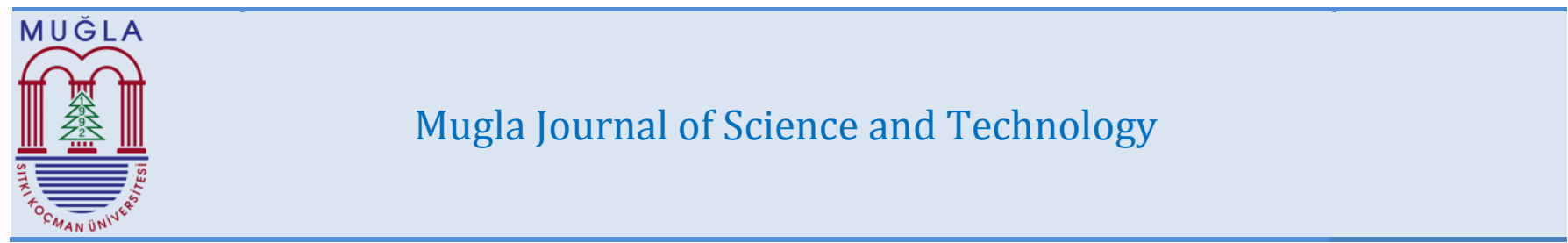

\title{
RECOVERY OF CYANIDE FROM EFFLUENTS USING CARBON DIOXIDE
}

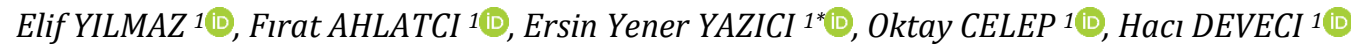

\begin{abstract}
${ }^{1}$ Hydromet B\&PM Research Group, Karadeniz Technical University, Department of Mining Engineering, Trabzon, TURKEY
elifkoc@ktu.edu.tr, eyazici@ktu.edu.tr, firatahlatci@ktu.edu.tr, ocelep@ktu.edu.tr, hdeveci@ktu.edu.tr
\end{abstract}

Received: 27.10.2017, Accepted: 07.12.2017

*Corresponding author

doi: $10.22531 /$ muglajsci.346041

\begin{abstract}
Cyanidation effluents are treated in order to reduce the cyanide level down to regularity limits. Cyanide recovery is the most desired route for treatment of effluents of high cyanide consuming ores, in particular, due to economic and environmental incentives. In this study, carbon dioxide (CO2) was utilised as an alternative for acidification of cyanide solutions prior to absorption/recovery of hydrogen cyanide (HCN(g)) in alkaline solutions. Kinetic tests indicated that reaction time was an important parameter for the recovery of cyanide, which reached 89.1\% over a period of 90 min. Effects of concentration of cyanide (0.5-1.5 g/L NaCN), flow rate of carbon dioxide (0.38-1.15 L/min. CO2), and time (30-90 min.) on the recovery of cyanide (\%) were investigated in detail by a two-level full factorial design (23). The statistical evaluation of the data showed that flow rate of carbon dioxide and time were statistically significant parameters. Efficiency of the process was not affected by the concentration of cyanide. The results demonstrated that high recoveries of cyanide up to $93.1 \%$ could be achieved under suitable conditions. Introduction of air (1.15 L/min.) as a carbon dioxide source was found to be inefficient and require longer reaction periods for high recoveries i.e. no recovery at 90 min. vs. $95.4 \%$ at 24 h. A separate test performed using a real pregnant leaching solution (PLS) yielded a cyanide recovery of 49.7\%. These finding demonstrated that using carbon dioxide can be used for acidification of cyanide solutions for cyanide recovery.
\end{abstract}

Keywords: Cyanide recovery, Carbon dioxide, Acidification, Experimental design

\section{KARBON DİOKSİT İLE ATIK ÇÖZELTÍLERDEN SIYYANÜR GERİ KAZANIMI}

$\ddot{0} \mathrm{z}$

Siyanür liçi işlemleri sonucu üretilen atık çözeltiler, siyanür içeriğinin yasal sınırlara indirilebilmesi için arıtma işlemine tabi tutulmaktadır. Siyanür geri kazanımı ekonomik ve çevresel nedenlerden dolayı, özellikle siyanür tüketimi yüksek cevherler için en çok tercih edilen seçenektir. Bu çalışmada, alkali çözeltilerde hidrojen siyanürün (HCN(g)) absorpsiyonu/geri kazanımı öncesinde siyanür çözeltilerinin asitlestirilmesi amacıyla karbon dioksit (CO2) kullanılmıștır. Yapılan kinetik testler, reaksiyon süresinin siyanür geri kazanımında önemli bir rol oynadığını göstermiştir (90 dk.'da \%89,1 siyanür geri kazanımı). Siyanür konsantrasyonu (0,5-1,5 g/L NaCN), karbon dioksit akıș debisi (0,38-1,15 L/dk. CO2) ve süre'nin (30-90 dk.) siyanür geri kazanımı (\%) üzerindeki etkisi iki seviyeli tam faktöriyel deney tasarımı kullanılarak araştırılmıștır. Verilerin istatistiksel analizi karbon dioksit akış hızı ve süre'nin istatistiksel olarak anlamlı parametreler olduğunu göstermiștir. Siyanür konsantrasyonunun prosesin etkinliği üzerinde bir etkisinin olmadığı belirlenmiștir. Elde edilen sonuçlar, uygun koșullarda \%93,1'e varan yüksek siyanür geri kazanımlarına ulaşılabileceğini göstermiștir. Karbon dioksit kaynağı olarak hava (1,15 L/dk.) kullanılmanın etkin olmadığı ve yüksek verimler için daha uzun süre gerektiği bulunmuştur (15 dk.'da kazanım sıfır iken 24 saatte \%95,4 olmuştur). Gerçek bir yüklü liç çözeltisinden yapılan testte \%49,7 verim elde edilmiștir. Elde edilen bulgular karbon dioksitin siyanürlü atık çözeltilerin asitleştirilmesinde ve siyanürün geri kazanımında kullanılabileceğini göstermiştir. Anahtar Kelimeler: Siyanür geri kazanımı, Karbon dioksit, Asitleștirme, Deney tasarımı.

\section{Introduction}

Over a century, leach plants utilise cyanide to extract gold/silver from ores [7], [19]. The non-selective nature of cyanide leaching results in contamination of leach solutions with other metals e.g. copper, zinc and iron[4], [10]. Effluents generated in leach plants should be treated due to environmental concerns with regard to toxic effects of cyanide [3], [6], [17], [22]. Regulatory bodies force to reduce the cyanide level (CNWAD) down to $<10 \mathrm{mg} / \mathrm{L}$ prior to discharge into tailings dam [23]. Chemical oxidation methods using $\mathrm{SO}_{2}$ /Air and $\mathrm{H}_{2} \mathrm{O}_{2}$ are commonly preferred for destruction of free cyanide $\left(\mathrm{CN}^{-}\right)$and metal-cyanide complexes (particularly weak acid dissociable (WAD) cyanides, $\log K \leq 30$ ) to convert/oxidise them into non-toxic compounds i.e. cyanate (OCN-) [17], [18], [21], [29], [30]. There are also several cyanide recovery/recycling methods available, which allow recovery and reuse of cyanide in leaching [9], [14], [24], [26]. One of the most common processes developed for cyanide recovery/recycling is AVR (acidification-volatilisationreabsorption). Similar processes (i.e. CRP and Cyanisorb) were also developed based on the principles of AVR [1], [21]. AVR process simply relies on the acidification $(<\mathrm{pH} 5)$ of cyanide effluent using $\mathrm{H}_{2} \mathrm{SO}_{4}$ (Eq. 1), volatilisation of HCN gas (Eq. 2), and its subsequent absorption in an alkaline solution $(\mathrm{NaOH}$ or $\mathrm{Ca}(\mathrm{OH})_{2}$ ) to form $\mathrm{NaCN}$ or $\mathrm{Ca}(\mathrm{CN})_{2}$ solution (Eq. 3) [16], [25], [27]. Formation of HCN under $\mathrm{E}_{\mathrm{h}}$ and $\mathrm{pH}$ conditions is shown in Figure 1.

$$
\begin{array}{lc}
2 \mathrm{CN}^{-}+\mathrm{H}_{2} \mathrm{SO}_{4} \rightarrow 2 \mathrm{HCN}(\mathrm{a})+2 \mathrm{SO}_{4}^{-2} & \text { (Acidification) } \\
\mathrm{HCN}(\mathrm{a}) \rightarrow \mathrm{HCN}(\mathrm{g}) & \text { (Volatilisation) } \\
\mathrm{HCN}(\mathrm{g})+\mathrm{NaOH} \rightarrow \mathrm{NaCN}+2 \mathrm{H}_{2} \mathrm{O} & \text { (Reabsorption) }
\end{array}
$$

Recently, SART process (sulphidisation-acidification-recyclingthickening) is developed to recover cyanide and copper (as a by-product) from high copper containing leach solutions [2], [8], [28]. The major benefit of cyanide recovery/recycling is its contribution to process economics [13].

A significant saving could be achieved in operating costs if cyanide recovery is preferred over cyanide destruction methods [13]. Cyanide recovery processes such as AVR process suffer from high consumption of acid to acidify alkaline leach solutions ( $\mathrm{pH}$ 10.5-11). Solid/liquid separation 
is also required in this process since the presence of solids decreases its efficiency by prolonging HCN volatilisation and increases acid consumption by up to 10 -fold depending on the
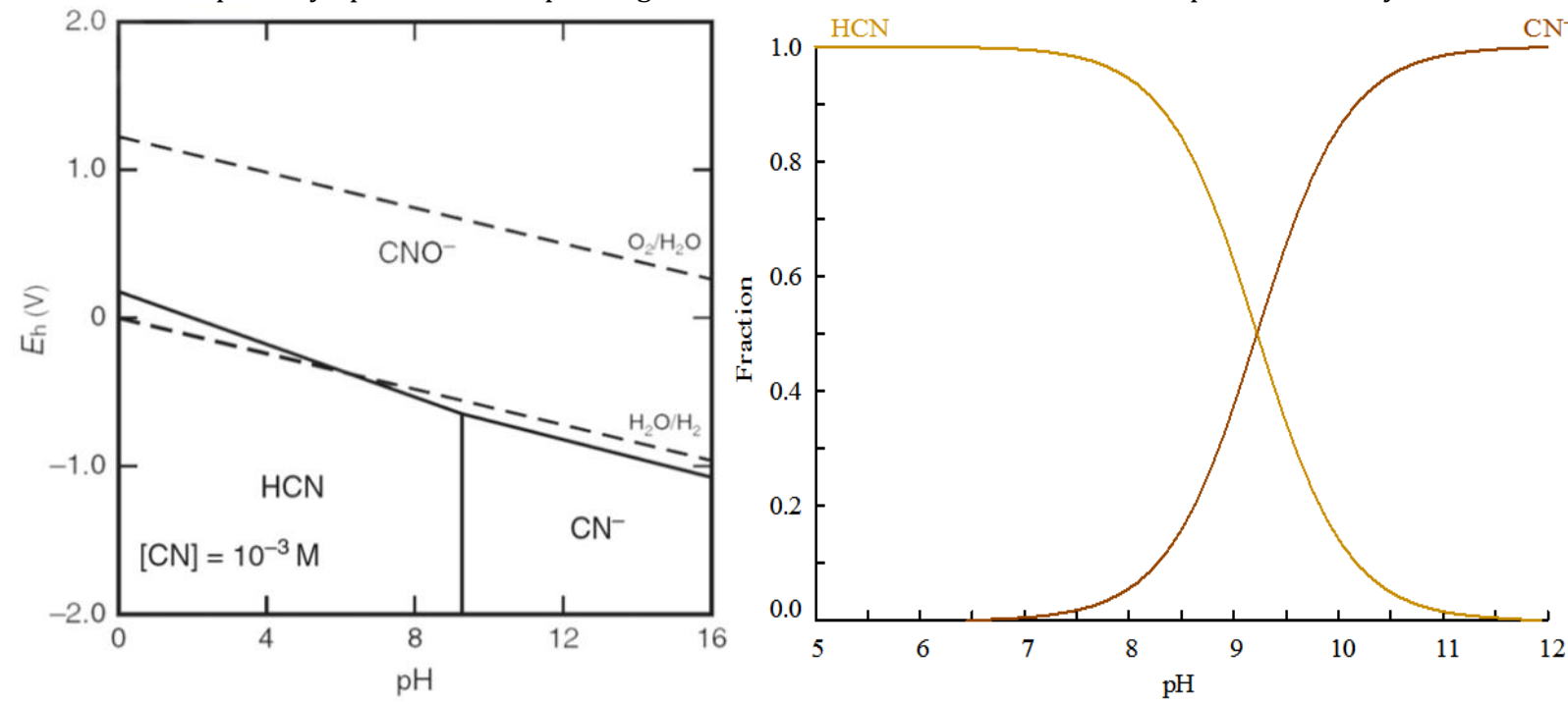

Figure 1. Eh-pH diagram of $\mathrm{CN}-\mathrm{H}_{2} \mathrm{O}$ system (left) [19] and pH dependent speciation of cyanide (right) (pKa=9.31) [20] ([CN- $]_{\mathrm{T}}: 10^{-3} \mathrm{M}$, $\left.25^{\circ} \mathrm{C}\right)$

In this study, carbon dioxide $\left(\mathrm{CO}_{2}\right)$ was utilised for acidification of cyanide solutions prior to absorption/recovery of hydrogen cyanide $\left(\mathrm{HCN}_{(\mathrm{g})}\right)$ in alkaline solutions. Effects of concentration of cyanide $(0.5-1.5 \mathrm{~g} / \mathrm{L} \mathrm{NaCN})$, flow rate of carbon dioxide (0.38-1.15 L/min. $\left.\mathrm{CO}_{2}\right)$, and time (30-90 min.) on the recovery of cyanide (\%) were investigated in detail by a two-level full factorial design. The efficiency of the method was tested on a real cyanide solution. The use of air as carbon dioxide source was also tested.

\section{Materials and Methods}

\subsection{Reagents and Experimental Set-up}

Sodium cyanide $(\geq 99.0 \% \mathrm{NaCN})$, silver nitrate $(\geq 99.5 \%$ $\mathrm{AgNO}_{3}$ ) and sodium hydroxide ( $\geq 99.0 \% \mathrm{NaOH}$ ) were used to prepare solutions in deionised and distilled water. Free presence of acid-consuming minerals in the ore [15] Therefore, alternative approaches are needed for efficient and cost-effective acidification processes for cyanide recovery. cyanide was analysed using silver nitrate titration with pdimethylaminobenzylrhodanine $(0.02 \% \mathrm{w} / \mathrm{w}$ in acetone) as indicator. A digital burette was used in the titration.

Cyanide recovery tests were performed using the system illustrated in Figure 2. Carbon dioxide (99.99\% $\left.\mathrm{CO}_{2}\right)$ was sparged into the reactor containing $200-\mathrm{mL}$ cyanide solutions (initial $\mathrm{pH} \approx 11$ ) at predetermined flow rates controlled by a flow meter. Cyanide solution in the reactor was acidified by carbon dioxide and volatilised HCN gas was transferred into the subsequent three-stage absorption units. A preliminary test showed that $\mathrm{pH}$ of cyanide solution $(1.5 \mathrm{~g} / \mathrm{L} \mathrm{NaCN})$ rapidly decreased below 6 in $5 \mathrm{~min}$. Concentrated solutions of sodium hydroxide (4 $\mathrm{M} \mathrm{NaOH})$ and a saturated solution of lime were used in the absorption reactors.

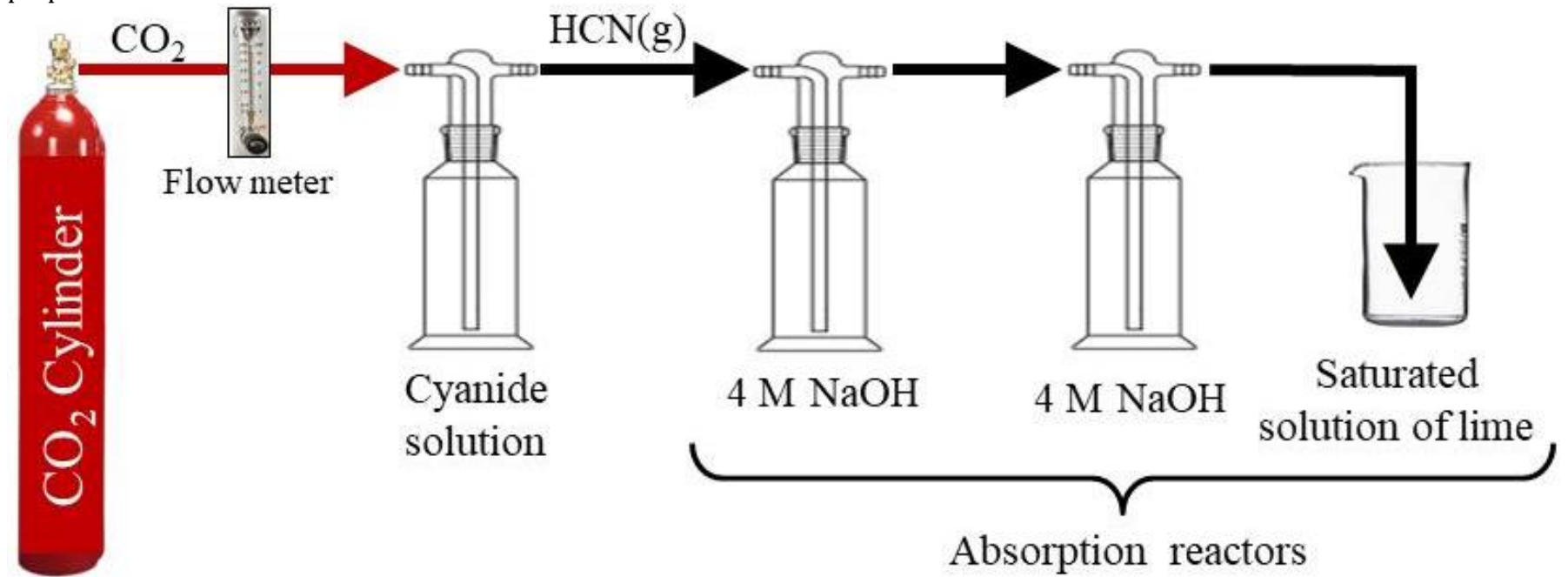

Figure 2. Experimental set-up used for the cyanide recovery tests

After the termination of each test, the acidified cyanide solution was neutralised using $\mathrm{NaOH}$. Neutralised cyanide solutions and solutions in the absorption reactors were analysed for free cyanide to calculate the cyanide recoveries (\%). The tests were performed at room temperature. A separate test was also performed using a real leach solution (LS) under the conditions of $1.15 \mathrm{~L} / \mathrm{min} \mathrm{CO}_{2}$ over 90 min. The 


\subsection{Experimental Design}

A two-level full factorial design was adopted to investigate the effects of initial concentration of cyanide (0.5-1.5 g/L NaCN), flow rate of carbon dioxide $\left(0.38-1.15 \mathrm{~L} / \mathrm{min} . \mathrm{CO}_{2}\right)$ and time (30-90 min.) on the recovery of cyanide (\%) (Table 1). The results were evaluated using a statistical software i.e. DesignExpert (2010).

Table 1. Investigated parameters with levels

\begin{tabular}{lll}
\hline & \multicolumn{2}{l}{ Levels } \\
\cline { 2 - 3 } Parameters & $\begin{array}{ll}\text { Low } \\
(-1)\end{array}$ & $\begin{array}{l}\text { High } \\
(+1)\end{array}$ \\
\hline A - Concentration of NaCN (g/L) & 0.5 & 1.5 \\
B - Flow rate of carbon dioxide (L/min) & 0.38 & 1.15 \\
C - Time (min.) & 30 & 90 \\
\hline
\end{tabular}

\section{Results and Discussion}

Figure 3 shows the kinetics of recovery of cyanide from a solution of $2 \mathrm{~g} / \mathrm{L} \mathrm{NaCN}$ over a period of $90 \mathrm{~min}$. at 1.15 $\mathrm{L} / \mathrm{min}$. $\mathrm{CO}_{2}$. The cyanide recovery was determined to be $36.3 \%$ in the first $15 \mathrm{~min}$. and it increased to $89.1 \%$ by prolonging the reaction period to $90 \mathrm{~min}$. (Figure 3). This indicated the significance of reaction time for the performance of cyanide recovery process.

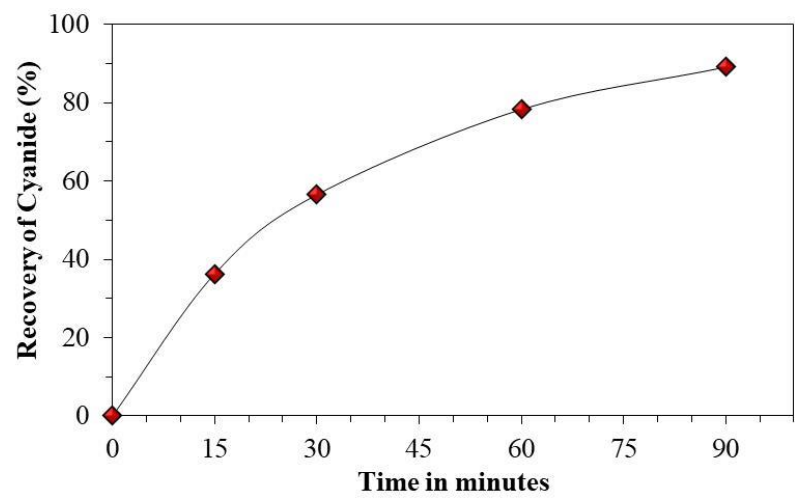

Figure 3. Kinetics of cyanide recovery using carbon dioxide (1.15 L/min. $\left.\mathrm{CO}_{2}, 2 \mathrm{~g} / \mathrm{L} \mathrm{NaCN}\right)$

The mechanism of cyanide recovery by carbon dioxide relies on the acidifying effect of carbon dioxide. Carbon dioxide dissolves in water (Eq. 4) and produce carbonic acid $\left(\mathrm{H}_{2} \mathrm{CO}_{3}\right)$ (Eq. 5), bicarbonate ( $\mathrm{HCO}_{3}{ }^{-}$) (Eq. 6) and carbonate $\left(\mathrm{CO}_{3}{ }^{2-}\right.$ ) ions (Eq. 7). Hydrogen ion $\left(\mathrm{H}^{+}\right)$is generated during these reactions leading to acidification of solutions [5], [19]. pH-dependent speciation of carbonate ion is presented in Figure 4. Carbonate ion $\left(\mathrm{CO}_{3}{ }^{2-}\right)$ is the dominant form in alkaline pHs of above $\approx 10$. Bicarbonate $\left.\left(\mathrm{HCO}_{3}\right)^{-}\right)$is stable in the $\mathrm{pH}$ range of $6.4-10$. Carbonic acid $\left(\mathrm{H}_{2} \mathrm{CO}_{3}\right)$ starts to dominate the medium below $\approx \mathrm{pH}$ 6.4. HCN starts to volatilise (Eq. 2, Figure 1) from the medium by the decrease in $\mathrm{pH}$ where $\mathrm{HCO}_{3}{ }^{-}$and $\mathrm{H}_{2} \mathrm{CO}_{3}$ are dominant. Since these reactions (Eqs. 5-7) are reversible, the system $\left(\mathrm{CO}_{2}\right.$ (weak acid)/ $/ \mathrm{HCO}_{3}$-(weak base)) reaches a dynamic equilibrium i.e. buffering the medium and stabilise $\mathrm{pH}$. The acidifying effect of $\mathrm{CO}_{2}$ present in air also leads HCN volatilisation in tailings ponds [12].

$\mathrm{CO}_{2}(\mathrm{~g})+\mathrm{H}_{2} \mathrm{O} \leftrightarrow \mathrm{CO}_{2}(\mathrm{a})+\mathrm{H}_{2} \mathrm{O}$

$\mathrm{CO}_{2}($ a $)+\mathrm{H}_{2} \mathrm{O} \leftrightarrow \mathrm{H}_{2} \mathrm{CO}_{3}$

$\mathrm{H}_{2} \mathrm{CO}_{3} \leftrightarrow \mathrm{H}^{+}+\mathrm{HCO}_{3}^{-}$ $\mathrm{p} K_{\mathrm{a} 1}=6.35$

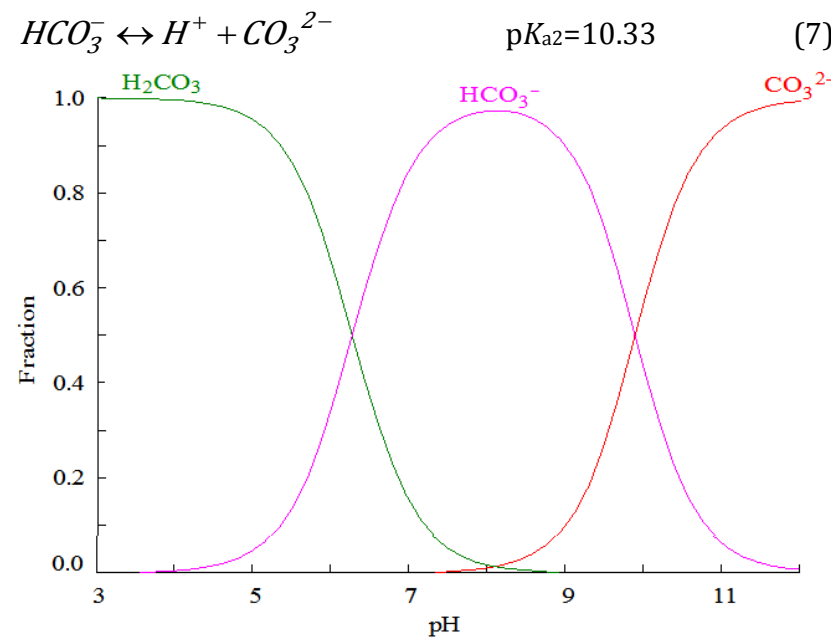

Figure 4. $\mathrm{pH}$ dependent speciation of carbonate ion $\left(\left[\mathrm{CO}_{3}{ }^{2-}\right]_{\mathrm{T}}\right.$ : $\left.0.1 \mathrm{M}, 25^{\circ} \mathrm{C}\right)[20]$

It is relevant to note that in a previous study [31] air oxidation of cyanide $\left(100 \mathrm{mg} / \mathrm{L} \mathrm{CN}^{-}\right.$, initial $\left.\mathrm{pH} 12.5\right)$ was studied in a similar system used in the current study. The authors noted that $\mathrm{pH}$ had a tendency to decrease apparently by the transfer of carbon dioxide in air into the solution. They observed that at $<\mathrm{pH} 10.5$ cyanide was readily volatilised from the solution and entrapped in the absorption reactor.

The influence of concentration of $\mathrm{NaCN}(0.5-1.5 \mathrm{~g} / \mathrm{L})$, flow rate of carbon dioxide $\left(0.38-1.15 \mathrm{~L} / \mathrm{min} . \mathrm{CO}_{2}\right)$ and time $(30-90$ min.) on the recovery of cyanide (\%) was investigated using a two-level full factorial design $\left(2^{3}\right)$. Experimental conditions of each run with corresponding responses (i.e. recovery of cyanide, \%) are shown in Table 2 . Cyanide recoveries were found to vary between $42.4 \%$ and $93.1 \%$ indicating that high recoveries could be achieved under suitable conditions (Table 2).

The statistical evaluation of the data indicated that among all the regression terms, only linear terms of time (C) and flow rate of $\mathrm{CO}_{2}$ (B) were found to be significant with high contributions of $56 \%$ and $44 \%$, respectively, on the cyanide recovery (Figure 5). Initial concentration of cyanide solution was found to be statistically insignificant. The analysis of variance (ANOVA) for the regression model (excluding the insignificant terms) was presented in Table 3 . The regression model and terms (B and C) were statistically significant at 99.9\% confidence level $(\alpha=0.001)$. The regression model is shown in Eq. 8. The positive terms of the model implied that increasing the flow rate of carbon dioxide and time improves the recovery of cyanide. The coefficient of multiple determinations $\left(\mathrm{R}^{2}\right)$ of the model was calculated to be $99.4 \%$. Recovery of Cyanide (\%) $=67.71+11.42 * \mathrm{~B}+12.96 * \mathrm{C}$ The simultaneous effect of flow rate of carbon dioxide (B) and time (C) on the cyanide recovery (\%) can be clearly seen from the surface plot (Figure 6). The parameters had a synergistic effect on the cyanide recovery suggesting that high recoveries could be achieved if high flow rate of carbon dioxide is maintained at prolonged periods. 
Table 2. Experimental layout showing the conditions with corresponding results for the recovery of cyanide (\%)

\begin{tabular}{lcccc}
\hline \multirow{2}{*}{ Exp. No } & $\mathrm{A}$ & Parameters with levels & \\
& Conc. of NaCN (g/L) & B & F & Recovery of Cyanide (\%) \\
\hline 1 & 0.5 & 0.38 & 30 & 45.9 \\
2 & 1.5 & 0.38 & 30 & 42.4 \\
3 & 0.5 & 1.15 & 30 & 65.1 \\
4 & 1.5 & 1.15 & 30 & 65.6 \\
5 & 0.5 & 0.38 & 90 & 69.6 \\
6 & 1.5 & 0.38 & 90 & 67.3 \\
7 & 0.5 & 1.15 & 90 & 93.1 \\
\hline
\end{tabular}

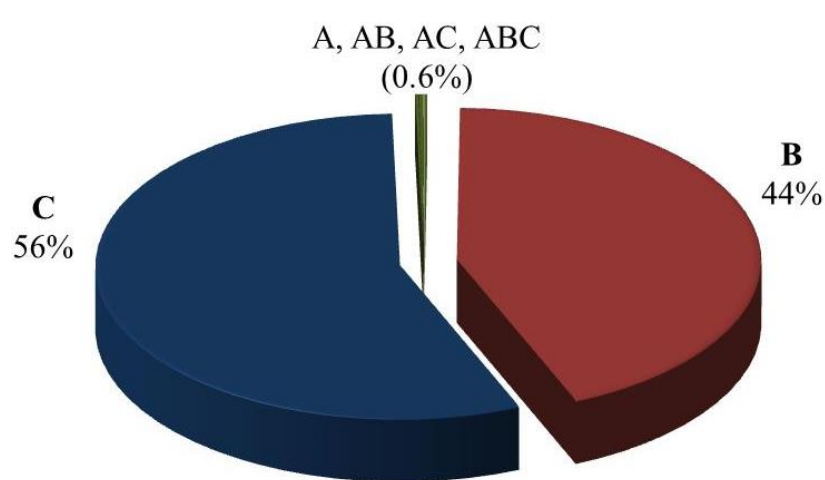

Figure 5. Contribution (\%) of the terms on the recovery of cyanide (\%)

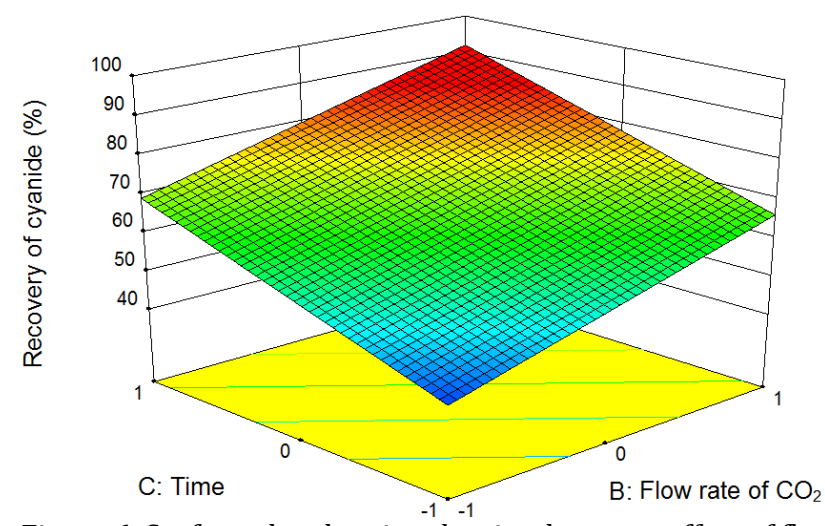

Figure 6. Surface plot showing the simultaneous effect of flow rate of carbon dioxide (B) and time (C) on the cyanide recovery (\%)

Introduction of air (1.15 L/min.) as a carbon dioxide source was also tested under the conditions of $0.5 \mathrm{~g} / \mathrm{L} \mathrm{NaCN}$ over 90 min. In contrast to high cyanide recovery (i.e. 93.1\%, Exp. 7) by using carbon dioxide (Table 2), the cyanide recovery was negligible over $90 \mathrm{~min}$. (Figure 7). This could be attributed to the limited availability of $\mathrm{CO}_{2}$ in air. However, prolonging the reaction period to $24 \mathrm{~h}$. substantially improved the cyanide recovery to $95.4 \%$ (Figure 7 ). This suggested that air could be also used in cyanide recovery as a source carbon dioxide at the expense of low reaction kinetics.

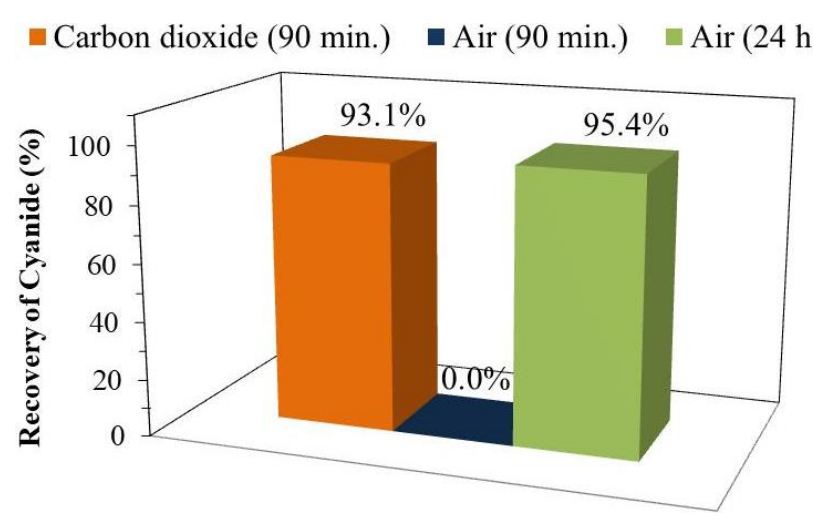

Figure 7. Effect of air on the recovery of cyanide (Gas flow rate: $1.15 \mathrm{~L} / \mathrm{min} ., 0.5 \mathrm{~g} / \mathrm{L} \mathrm{NaCN}$ )

Separate tests on a real leach solution (LS) $(1.15 \mathrm{~L} / \mathrm{min}$. carbon dioxide, $90 \mathrm{~min}$ ) yielded a cyanide recovery of $49.7 \%$. No precipitation of metals was noted during the test. This implied that $\mathrm{pH}$ was not sufficiently low to release cyanide from metal-cyanide complexes. The dissociation of metalcyanides with regard to $\mathrm{pH}$ is shown in Figure 8. Strong acid dissociable cyanides (SAD; $\log K>30$ ) like $\mathrm{Au}, \mathrm{Co}$ and $\mathrm{Fe}$ is very stable even at low pHs while weak acid dissociable cyanides (WAD; $\log K \leq 30$ ) (e.g. $\mathrm{Zn}$ and $\mathrm{Cu}$ ) starts to release their complexed cyanide relatively at higher pHs. It may be inferred that prolonging the reaction period may further decrease $\mathrm{pH}$ and hence improve cyanide recoveries despite the fact that copper-cyanide and SAD cyanides would be still stable unless acidic conditions $(<\mathrm{pH} 4)$ are not achieved (Figure 8).

Table 3. Analysis of variance (ANOVA) for the regression model of cyanide recovery

\begin{tabular}{llllll}
\hline Source & $\begin{array}{l}\text { Sum of } \\
\text { Squares }\end{array}$ & df & $\begin{array}{l}\text { Average } \\
\text { squares }\end{array}$ & $\begin{array}{l}\mathrm{F} \\
\text { value }\end{array}$ & P value \\
\hline $\begin{array}{l}\text { Model } \\
\text { B - Flow rate } \\
\quad \text { of } \mathrm{CO}_{2}\end{array}$ & 1044 & 2 & 1194 & 420 & $<0.0001$ \\
C - Time & 1344 & 1 & 1344 & 472 & $<0.0001$ \\
$\begin{array}{l}\text { Error } \\
\text { Total }\end{array}$ & 14 & 5 & 3 & & \\
\hline
\end{tabular}

\section{Conclusions}

Treatment of cyanide effluents is pre-requisite for environmental reasons. Cyanide recovery is preferred over chemical destruction due to economic and environmental benefits. In this current study, the use of carbon dioxide was investigated to acidify cyanide solutions in order to 
volatilise $\mathrm{HCN}$ gas and absorb/recover in the subsequent stage. The results showed the importance of reaction period for achieving high recoveries. A two-level full factorial design experiments showed that a high recovery of $93.1 \%$ could be achieved under suitable conditions. The flow rate of $\mathrm{CO}_{2}$ and reaction time were found to be statistically significant parameters for cyanide recovery. Air could be used as a carbon dioxide source, but, cyanide recovery occured very slowly in the presence of air compared with carbon dioxide e.g. no recovery at $90 \mathrm{~min}$. vs. $95.4 \%$ at 24 h. The process $\left(1.15 \mathrm{~L} / \mathrm{min}\right.$. $\mathrm{CO}_{2}, 90 \mathrm{~min}$.) was also tested on a leach solution (LS) with a relatively low cyanide recovery of $49.7 \%$. This could be attributed to the failure to achieve sufficient acidity to break down some WAD/SAD cyanides present in LS. The findings demonstrated that carbon dioxide could be used for acidification of cyanide solutions for cyanide recovery.

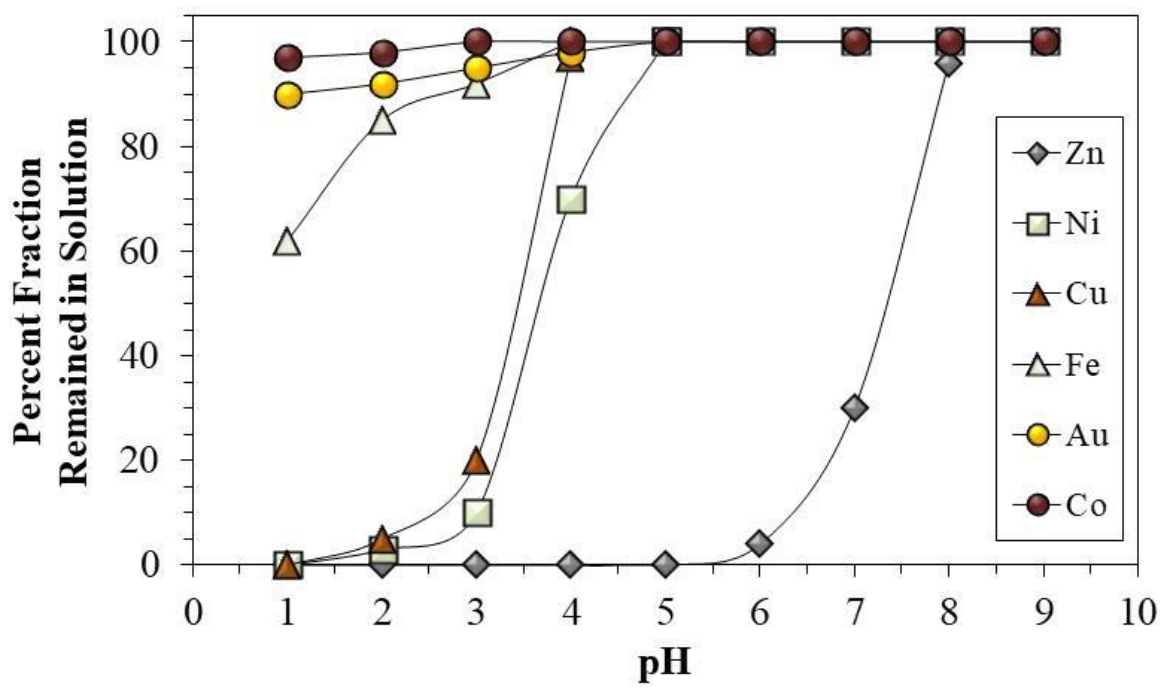

Figure 8. pH dependent dissociation of metal-cyanide complexes [19]

\section{Acknowledgment}

This study was previously presented at International Symposium on Mining and Environment (ISME 2017)

\section{References}

[1] Adams, M. and Lloyd, V., "Cyanide recovery by tailings washing and pond stripping", Minerals Engineering, 21, 501508, 2008.

[2] Adams, M.D., "Impact of recycling cyanide and its reaction products on upstream unit operations", Minerals Engineering, 53, 241-255, 2013.

[3] Akcil, A., "First application of cyanidation process in Turkish gold mining and its environmental impacts", Minerals Engineering, 15, 695-699, 2002.

[4] Bas, A.D., Yazici, E.Y. and Deveci, H., "Treatment of a copper- rich gold ore by ammonia assisted cyanide leaching", XXVI. International Mineral Processing Congress (IMPC), New Delhi, pp. 356-365, 2012.

[5] Benjamin, M., Water chemistry, McGraw-Hill, 668 pages, 2001.

[6] Botz, M.M., Mudder, T.I. and Akcil, A.U. (Mike, D.A., Wills, B.A.), Developments in Mineral Processing, "Cyanide treatment: Physical, chemical and biological processes", Elsevier, pp. 672-702, 2005.

[7] Celep, O., Altın Cevherlerinin Zenginleştirilmesi, Türkiye Alim Kitapları, 220 pages, 2015.

[8] Dai, X., Simons, A. and Breuer, P., "A review of copper cyanide recovery technologies for the cyanidation of copper containing gold ores", Minerals Engineering, 25, 1-13. 2012.

[9] Demopoulos, G.P. and Cheng, T.C., "A case study of CIP tails slurry treatment: comparison of cyanide recovery to cyanide destruction", The European Journal of Mineral Processing and Environmental Protection (EJMP\&EP), 4, 19, 2004.
[10] Deschênes, G. and Prud'homme, P.J.H., "Cyanidation of a copper-gold ore", International Journal of Mineral Processing, 50, 127-141, 1997.

[11] Design-Expert, 2010, DOE Software, Stat-Ease Inc., Minneapolis, USA, 8.0.7.1, USA.

[12] Dobrosz-Gómez, I., García, B.D.R., GilPavas, E. and García, M.Á.G., "Kinetic study on HCN volatilization in gold leaching tailing ponds", Minerals Engineering, 110, 185-194, 2017.

[13] Fleming, C.A., "The Economic and environmental case for recovering cyanide from gold plant tailings", SGS Minerals Services, Technical Paper \#2003-02, 2003.

[14] Fleming, C.A., (Mike, D.A., Wills, B.A.), Developments in Mineral Processing, "Cyanide recovery", Elsevier, pp. 703727, 2005.

[15] Fleming, C.A., "Cyanide management in the gold industry", SGS Minerals Services, Technical Paper \#2010-04, 2010.

[16] Gönen, N., Kabasakal, O.S. and Özdil, G., "Recovery of cyanide in gold leach waste solution by volatilization and absorption", Journal of Hazardous Materials, 113, 231-236, 2004.

[17] Johnson, C.A., "The fate of cyanide in leach wastes at gold mines: An environmental perspective". Applied Geochemistry, 57, 194-205, 2015.

[18] Kuyucak, N. and Akcil, A., "Cyanide and removal options from effluents in gold mining and metallurgical processes", Minerals Engineering, 50-51, 13-29, 2013.

[19] Marsden, J. and House, I., "The chemistry of gold extraction", Society for Mining, Metallurgy, and Exploration, USA, 688 pages, 2006.

[20] Medusa, 2009, Software for chemical equilibrium diagrams, 32 bit version. Royal Institute of Technology, Sweden.

[21] Mudder, T.I. and Botz, M.M., The chemistry and treatment of cyanidation wastes, Mining Journal Books Ltd, London, 393 pages, 2001. 
[22] Mudder, T.I. and Botz, M.M., "Cyanide and society: a critical review", The European Journal of Mineral Processing and Environmental Protection (EJMP\&EP), 4, 62-74, 2004.

[23] Official Gazette, Regulation on Mining Wastes, Ministry of Environment and Urbanisation, Turkey, 15.07.2015, Issue: 29417, 2015.

[24] Ritcey, G.M., "Tailings management in gold plants", Hydrometallurgy, 78, 3-20, 2005.

[25] Riveros, P.A., Molnar, A.R. and Baša, F., "Treatment of a high-cyanide waste solution for cyanide and metal recovery", CIM Bulletin 89, 153-156, 1996.

[26] SGS, "Cyanide Recovery", T3 SGS 019, Technical Paper, SGS Minerals Services, 2009.

[27] Vapur, H. and Bayat, O., "Prediction of cyanide recovery from silver leaching tailings with AVR using multivariable regression analysis", Minerals Engineering, 20, 729-737, 2007.

[28] Xie, F., Dreisinger, D. and Doyle, F., "A Review on recovery of copper and cyanide from waste cyanide solutions", Mineral Processing and Extractive Metallurgy Review, 34, 387-411, 2013.

[29] Yazıc1, E.Y., "Removal of cyanide from wastewaters using hydrogen peroxide, activated carbon adsorption and ultrasonic waves", M.Sc. Thesis, Karadeniz Technical University, Trabzon, Turkey (in Turkish), 2005.

[30] Yazıcı, E.Y., Deveci, H., Alp, I., Uslu, T. and Celep, O., "Factors affecting decomposition of cyanide by hydrogen peroxide", XXIII. International Mineral Processing Congress (IMPC), Istanbul, Turkey, 3-8 September, pp. 2439-2444, 2006.

[31] Yazıc1, E.Y., Deveci, H. and Alp, I., "Treatment of cyanide effluents by oxidation and adsorption in batch and column studies", Journal of Hazardous Materials, 166, 1362-1366, 2009. 